\title{
Wat is ' $n$ sakrament? \\ 'n Poging om ' $n$ antwoord te vind
}

GC VELTHUYSEN

Hierdie vraag kan maklik, simplisties en eendimensioneel beantwoord word. Die vraagsteller kan eenvoudig verwys word na wat in die belydenisskrifte staan en daarmee kan die saak as afgehandel beskou word. Dit is die één manier. Daar is egter ook 'n ander manier. Dit is wanneer die teoloog wat die antwoord moet verskaf, dit nuut en vars probeer sê - in byderwetse taal en begrippe - sodat dit vir 'n moderne oor toeganklik is en die moderne mens dit sal verstaan. Dan is die antwoord nie meer maklik nie. Dan word dit bykans onmoontlik om 'n eenduidige en afdoende antwoord te verstrek. Dan lyk dit asof die enigste antwoord wat werklik sin maak, 'n vraag is. 'n Vraag, omdat die misterie van die sakrament uiteindelik grotendeels ontoeganklik is. Daarom is hierdie poging om 'n antwoord te vind, ook uiteindelik niks meer as 'n vraag nie. Maar dit is óók ' $n$ antwoord.

\section{DOGMENHISTORIESE OORSIG}

Die vraag na die wese, die aard en die betekenis van die sakramente, kan nie op verantwoordelike wyse beantwoord word as daar nie kennis geneem word van die eeuelange worsteling van die kerk in hierdie verband nie. Die feit is naamlik dat "sakrament" nie 'n Bybelse begrip is nie. Afgesien daarvan ken die Nuwe Testament ook nie die saamgroepering van bepaalde goddelike genademiddels wat met hierdie begrip aangedui sou kon word nie. Die Skrifte ken met ander woorde nie so iets as 'n sakramentsteologie nie en gee nie eers 'n ontwerp waarbinne so 'n teologie geformuleer sou kon word nie. Dit is daarom 'n saak wat grotendeels in die skoot van die kerk en sy teologie te lande kom. Hy het die vryheid om self te besluit watter heilsgoedere hy as sakramente wil beskou en wat hy presies daaronder verstaan.

Die begrip "sacramentum" word deur Tertullianus in die kerklike spraakgebruik ingevoer. Dit was ' $n$ interessante keuse, met verreikende gevolge. Die woord verwys oorspronklik na die sakrale krygseed of eed van trou wat deur soldate afgelê moes word. Hiervandaan het dit in gebruik geraak by die sogenaamde misteriegodsdienste waar dit 
aanduiding geword het van 'n verpligtende wydingshandeling wat bindende kultiese krag het. Tertullianus vind die begrip toe nommerpas as anduiding van daardie gegewenhede vanuit die heilsopenbaring waardeur God Homself verbind en wat vir die gelowiges onvoorwaardelik verpligtend, onaantasbaar en onvervreembaar is.

Aanvanklik word die woord veral gebruik as aanduiding van die doop, maar spoedig ook van die nagmaal. My ondersoek het dit nie kon aandui nie, maar dit is tog verduidelik om te spekuleer dat die nagmaal eers só genoem is, nadat die volgende ontwikkeling hom voltrek het.

Nadat "sacramentum" eers eenmaal in die spraakgebruik van die kerk ingeburger begin raak het, is dit ook deur die Latynse vertalings van die Nuwe Testament gebruik as weergawe van die Griekse "mustērion" (bv Ef 5: 32). Die gevolg hiervan was dat die ryk en diepsinnige betekenisskakerings van dié woord die betekenis van "sakrament" verryk. "Mustērion" verwys steeds na die objek van die verkondiging na die kwaliteit van die heilsgebeure self - na die geheimenis van die heilshandeling en heilsbeskikking van God.

Sodoende verkry die begrip "sakrament", soos dit in die kerk funksioneer, ' $n$ rykdom aan betekenis, wat dit moontlik maak om dit op verskillende maniere te interpreteer. Dit word moontlik om die saak, wat deur die woord beskryf word, te beskou as ò ' $n$ handeling van God waardeur Hy heil aan die ontvanger skenk, òf 'n handeling waarin die mense die handelende subjek is en die handeling as pligteken vervul, ò 'n handeling wat as simbool heenwys na die geheimenis van God se heilsdaad in Jesus Christus wat geglo moet word, òf as 'n handeling waarin al hierdie moontlikhede verdiskonteer word. In hierdie veelduidigheid van die begrip "sakrament", lê die kiem van al die stryd wat rondom die saak van die sakrament sou losbars.

Die toekomstige stryd is al in embrio aanwesig in die sakramentsteologie van Augustinus - die eerste teoloog wat hom op sistematiese wyse met die sakramente besig gehou het. Sy beskouings vertoon soveel van bogenoemde dubbelslagtigheid, dat dit later vir Roomse én Protestantse teoloë moontlik was om hulle in dié verband op hom te beroep.

Hy was die eerste teoloog wat sistematiese belangstelling in die begrip "sakrament" as versamelbegrip vir die doop en die nagmaal gehad het en hy probeer daarom om die begrip eksak te definieer. Hy onderskei in die sakrament twee sake $\mathrm{nl}$ in die eerste plek die "signum" (die uiterlike handeling met die stoflike elemente) en daarnaas die "res" (die goddelike genadewerking). Beide gesamentlik is betrek 
op die werk van Jesus Christus, waarna die sakramente van die ou verbond vooruitwys en wat deur dié van die nuwe as vervul aangetoon word. Die "signum" en die "res" word deur die "verbum" (die stigtings- en wydingswoord) aan mekaar verbind. Daar kan bv net van 'n heilswerking van die nagmaal gepraat word, in soverre as wat die "verbum" geglo word. Augustinus beklemtoon hierdie geloof met betrekking tot die sakramente tot so 'n mate, dat dit byna die reële deelname aan die sakramente as sodanig, vervang. Daarteenoor lê hy male sonder tal klem op die heilsnoodsaaklikheid van die sakramente, veral met die oog op die kerk. Sy gedagtes is dat daar sonder die sakramente nie 'n kerk kan wees nie, en buite die kerk is daar geen heil nie. So is sy sakramentsteologie steeds bestempel deur dubbelslagtigheid: 'n aksent wat as spiritualisties aangedui kan word, teenoor een wat beskou kan word as effektief-realisties.

As 'n mens nou die verdere ontwikkeling tydens die sg Middeleeue vereenvoudig en in 'n neutedop saampers, kan gesê word dat veral hierdie effektief-realistiese aksent by Augustinus uitgebou is. Die effektiewe karakter van die sakramente word al meer en meer op die voorgrond gestoot.

Hulle bevat en bemiddel die genade. Dit gee daartoe aanleiding dat die vraag na die syn van die genadekragte in die gewyde elemente van die sakramente al meer aandag begin geniet. Die gevolg hiervan is dat die sakrament uiteindelik beskou is as 'n heils-"ding" - 'n handeling wat heil skenk. Dit word gesien as 'n kultiese handeling waarin gewyde, kultiese elemente die hoofrol speel en waardeur die heil as 't ware in die ontvanger ingegiet word. Dit is heilsnoodsaaklik en werk ex opere operata (deur die gewerkte werk (sic!)) onder die voorwaarde dat daar aan die kant van die bedienaar die intensie (intention) is om te doen wat Christus en die kerk wil hê hy moet doen en aan die kant van die ontvanger die sekerheid dat hy hom nie skuldig gemaak het aan 'n doodsonde nie en dat hy nie weerstand bied teen die sakramentshandeling nie ("non ponere obicem").

Uiteindelik kan die volgende sake aangedui word as konstituerend vir die Roomse sakramentsbeskouing ten tye van die Reformasie: 'n Sewetal sakramente, ingestel deur Christus met effektiewe karakter (genadebemiddelend) en heilsnoodsaaklikheid wat ex opere operata werk (met inagneming van die "non ponere obicem") terwyl die doop, die vormsel in die priesterwyding ' $n$ "character indelebilis" verleen.

Vir die kerkhervormers, die herontdekkers van die Woord as die groot genademiddel van die Gees, was hierdie heilsobjektivisme geheel en al 
onaanvaarbaar. Die Woord word immers hierdeur grotendeels oorbodig gemaak en daarom moes dit met alle krag bestry word.

Dit is algemene kennis dat daar, wat hierdie saak betref, alles behalwe eenstemmigheid onder die hervormers was. ' $n$ Vereenvoudigde skematiese voorstelling sou die beskouing van Luther en Zwingli aan die twee verste punte plaas, met die van Calvyn iewers in die middel, as 'n poging om tussen die twee ekstreme houdings te bemiddel. 'n Beter voorstelling, nader aan die waarheid, sou wees om Calvyn se standpunt aan te dui as ' $n$ sintese tussen die genoemde uiterstes - maar dan op 'n hoër vlak, $n l$ die vlak van die Gees. Ten spyte van hierdie verskille is daar egter basiese, wesenlike ooreenkomste, wat dit moontlik maak om van 'n reformatoriese standpunt in dié verband te praat.

Hierbo is reeds gemeld dat die Roomse sakramentsteologie die heilsbemiddeling verdinglik het. Bepaalde stoflike elemente is gesien as draers van die heil, met die gevolg dat onstoflike oordragsvorme (soos die prediking), as van minder belang beskou is.

Teenoor hierdie verdingliking, dink die hervormers personaliserend. Volgens hulle visie kan die heil nie aan die mens oorgedra word deurdat dit ingegiet word, soos wanneer water in 'n kan gegooi word nie. Die basiese reformatoriese standpunt van die regverdiging deur die geloof alleen kon nie anders as om ook in die sakramentsbeskouing neerslag te vind nie. Daarom is die grondslag van die reformatoriese sakramentsteologie die standpunt dat dit net daar die heil werk waar dit in geloof ontvang word. Die ontvanger is dus in die hele proses aktief betrokke deurdat hy op ' $n$ bepaalde manier moet respondeer daar moet by hom geloof aanwesig wees. Dit is waarom die prediking so belangrik word. Die prediking proklameer die beloftes van God en rig'n dringende appèl tot die hoorders - 'n appèl tot geloofsaanvaarding van die heil wat in Christus aangebied word. Deur die prediking word die heil aangebied en daarom word dit in die kerke van die Reformasie die sentrale genademiddel - nie net langs nie, maar bokant die sakramente. Aangesien Calvyn die gematige sentristiese posisie in die reformatoriese sakramentskontrovers beklee, en sy standpunt gevolglik die een was wat die oorwinning behaal het, kan daar baie kortliks by stilgestaan word.

Dit moet steeds in gedagte gehou word dat hy in 'n polemiese situasie geskryf het. Gevolglik is sy sakramentsbeskouing hoofsaaklik geformuleer as weerlegging van ander standpunte. Dit is daarvoor verantwoordelik dat hy sy saak dikwels amper óór beargumenteer en in sy gretigheid om te weerlê, beurtelings feitlik oorhel na die ander 
uiterste. Wanneer dit nie in aanmerking geneem word nie, mag dit vir die oningewyde leser voorkom asof Calvyn homself aanhoudend weerspreek.

Teenoor die Zwingliane, handhaaf hy die standpunt dat God die subjek van die sakramente is en dat $\mathrm{Hy}$ dit gebruik tot verseëling en bevestiging van sy heilswoord en die versekering en versterking van ons geloof. Die sakramente werk nie uit eie krag nie. Die krag is dié van die Heilige Gees en die sakramente is niks anders as sy werktuie nie. Die krag is egter net vir die gelowige werksaam. Vir die ongelowige is die sakrament 'n leë teken, maar vir die gelowige het dit, deur die krag van die Gees, effektiewe betekenis.

Teenoor die Lutherane weer, stel hy dat die sakramente nie werklik meewerkende faktore in die heilsbemiddeling is nie. In die heilsekonomie van God is dit die taak van die prediking. Die sakramente moet hoogstens waardeer word as byvoegings by die Woord - bygevoeg as seëls en onderpande; en dit ter wille van ons stompsinnigheid. Hy stel byvoorbeeld dat die belofte van die Woord die uitwendige aanhangsel van die sakramente nie nodig het nie en dat God dit net bygevoeg het ter wille van ons stadige begrip (woorde wat hy in die verband gebruik is ignorantia, tarditas, infirmitas en imbecillitas). En op 'n ander plek stel hy dat God se genade nie aan die sakramente gebonde is nie en dat wanneer dit vir enige mens onmoontlik word om die sakramente van die kerk te ontvang, hy die genade deur geloof, uit die Woord van die Here verkry.

Selfs vir 'n oppervlakkige leser van die Institusie, behoort dit duidelik te wees dat Calvyn nooit die sakramente wou degradeer of relativeer nie. Wat hy wou doen was om die pneumatologiese karakter daarvan tot sy reg te laat kom. Hy wou die sakramente red van die materialistiese verdingliking en vervlakking wat dit in die amptelike Roomse teologie ondergaan het, en dit tuisbring binne die sfeer van die Gees. Hierdie is ' $n$ saak wat deur vele ten onregte aangedui is as ' $n$ neoplatoniese invloed (minagting van die stoflike ten gunste van die geestelike), maar wat verklaar moet word uit sy oortuiging dat God die Gees sy krag nie oordra aan stoflike elemente nie, maar dit hoogstens in diens neem. Sy klemlegging op Gees, Woord en geloof het geen ander doel nie as om die lof en eer van God te beskerm.

Hoe waar dit or $k$ al is, is dit ewe waar dat in hierdie beskouing van Calvyn die mousuitikheid opgesluit lê van dit wat hy juis wou vermy, nl die afskalering van die waarde van die sakramente. Die klemlegging op die prediking as die eintlike genademiddel, die ponering van die 
heilsnoodsaaklikheid daarvan terwyl dit nie van die sakramente waar is nie; die noodsaaklikheid van die Woord (prediking) by die sakrament alvorens dit werklik betekenis en werkende krag verkry, dra alles daartoe by dat die Woord en sy verkondiging die primêre posisie beklee (soos dit hoort), en dat die sakramente daardeur in 'n sekondêre posisie gestoot word, wat die oortuiging sou kon laat ontstaan dat hulle onbelangrik en dus onnodig is. Die ondervinding leer ook dat vele kerkmense, sekerlik onder invloed van die kerk se prediking, inderdaad so oor die sakramente voel.

'n Verdere bydraende faktor om hierdie gedagte te laat posvat, is die wanbegrip rondom die woord "teken" (signum), wat sedert Augustinus reeds gebruik word om die sakramente mee te definieer. Dit was 'n geheel adekwate woord om dit te doen, maar helaas nie meer vir moderne ore nie. Ons kan ons begrip van die woord "teken" baie moeilik (indien wel) losmaak van die moderne simboolbegrip. Volgens ons moderne opvatting is ' $n$ teken 'n sinnebeeld, maar dat dit wat gesimboliseer word iets anders is, wat nie in die simbool te vinde is nie. Volgens die antieke opvatting egter het die simbool ook deel aan die werklikheid wat dit simboliseer - die gesimboliseerde is daarin!

Dit is wat Augustinus bedoel en wat Calvyn bedoel (al is dit in pneumatologiese sin). Dit is egter nie duidelik of dit nog steeds is wat die deursnee lidmaat van die deursnee reformatoriese kerk bedoel nie.

\section{NADER AAN DIE EINTLIKE PROBLEEM}

Aan die begin van hierdie voordrag is gestel dat dit grotendeels aan kerk en teologie oorgelaat is om uitspraak te maak oor watter heilsgoedere hy as sakramente beskou en wat hy presies daaronder verstaan. Die rede hiervoor is dat geen saak in die Skrif as "sakrament" aangedui word nie, en daar gevolglik ook geen beredenering oor die betekenis van die begrip en die sake wat dit aandui, voorkom nie.

Hierdie vryheid van die kerk het, vanuit die staanspoor, aanleiding gegee tot groot verwarring. Nie net is verskillende handelings as sakramente aangedui nie, maar selfs ook verskillende sake wat daarby betrokke is.

Vir die een was die stoflike elemente die sakrament, vir 'n ander die handeling as sodanig, vir 'n derde een die twee sake gesamentlik terwyl vir Calvyn en die Reformasie dit nog wyer strek: vir hom is die hele geheimenisvolle handeling, die teken en die betekende saak die sakrament. In hierdie sin word die woord in die reformatoriese belydenisskrifte, en ook in hierdie voordrag gebruik. 
Die omskrywende definisie wat die Reformasie na vore gebring het in 'n poging om sy leer oor die sakramente vas te vat, is welbekend: Die sakramente is sigbare waartekens en seëls van ' $n$ inwendige en onsienlike saak, deur Jesus Christus ingestel om sy beloftes aan ons te verseël en sodat dit as pande kan dien van God se genade oor ons.

Dit is onmiddellik duidelik hoe die Reformasie sy vryheid tot interpretasie gebruik en sy vryheid van keuse uitgeoefen het om by hierdie definisie uit te kom.

Vanuit die baie handelinge in die lewe van die kerk wat as heilig en ook sakramenteel beskou sou kon word, word die getal effektief tot twee beperk deur die kwalifikasie van die instelling deur Jesus Christus.

Nou is dit so dat die moderne tekskritiek ernstige twyfel het of Jesus werklik die doop en die nagmaal ingestel het. En 'n intensiewe studie van die bronne sal inderdaad ook uiteindelik moet lei tot die bekentenis dat ons nie weet of die historiese Jesus of die Jesus van die geskiedenis dit wel gedoen het nie. Die bronne gee hieroor nie klinkklare uitspraak nie. Ons geloof is egter gelukkig nie gebou op 'n historiese Jesus wat vir ons deur die tekskritici ontdek moet word nie. Ons geloof steun op die Here van die kerk - die verheerlikte Christus wat deur die evangelie betuig word en vir wie ons nie meer na die vlees ken nie. En volgens die sinoptici en die getuienis van Paulus het die Here die doop en die nagmaal ingestel. Daaraan hou ons vas.

Wat hierdie sakramente werklik is, is 'n vraag wat egter nie maklik beantwoord kan word nie. Ons het reeds aandag gegee aan die betekenisinhoud van die woord "sakrament" en gesien dat die worsteling om begrip, wat so ' $n$ integrale deel van die geskiedenis van die teologie is, 'n aanduiding is dat die woord nie op genoegsame wyse uitdrukking gee aan wat hier ter sprake is nie.

Dit was juis die rede daarvoor dat die woord "teken" (in sy klassieke betekenis), deur Augustinus na vore gebring is. Hierdeur wou hy uitdrukking gee aan sy oortuiging dat die sakramente nie leë en oppervlakkige handelinge is nie maar dat God self, op 'n verborge en onbegryplike wyse, daarin aanwesig is. Hoe Hy aanwesig is, is nog weer 'n ander vraag, waarop talle uiteenlopende antwoorde gegee is, en waar die weë werklik uitmekaar gegaan het. Rome sê dat Jesus Christus werklik liggaamlik-stoflik aanwesig is in die elemente van die sakrament. Die Zwingliane weer sê dat $\mathrm{Hy}$ nie anders aanwesig is as dat $\mathrm{Hy}$ in herinnering geroep word nie. Calvyn se standpunt, wat die van die 
belydenisskrifte geword het, kom daarop neer dat $\mathrm{Hy}$ wel werklik aanwesig is, maar op die wyse van die Gees.

Waarom was die Reformasie dan nie tevrede met net die verkondiging van die Woord en die geloof in Jesus Christus en die teenwoordigheid van die Gees nie? Waarom nog sakramente? Die Gees gebruik tog mos die verkondiging van die Woord om by ons teenwoordig te wees. Ons ervaar gevolglik sy teenwoordigheid by ons en ons gemeenskap met Hom, onder die Woordverkondiging.

Waarom het die kerk as geheel nie die radikale konsekwensie van sekere radikale uitlopers soos die Kwakers en die Heilsleër getrek en die sakramente heeltemal links gelaat nie?

Die antwoord lê in die ondeurgrondelike geheim van die inkarnasie van Jesus Christus. Die finale en diepste grond vir die sakramente, is die vleeswording van die Woord.

Die kerk het dit nog altyd so verstaan dat die vleeswording van die Woord die aanduiding daarvan is dat die heil wat God skenk, nie net vir die gees van die mens bedoel is nie, maar dat dit ook sy vleeslikheid - sy liggaamlikheid omsluit. Daarom word die heil nie net by wyse van 'n gepredikte Woord onder die mense ingedra nie maar kom dit, in die persoon van Jesus van Nasaret, reëel onder ons en tussen ons woon.

Ons kan Hom egter nie meer direk só ervaar nie. Ons ken Hom mos nie meer na die vlees nie. Ons sou hierdie versekering van die realiteit van die heil moes ontbeer, as dit nie op 'n unieke manier by ons tuisgebring is nie. Jesus Christus word wel so aan ons deur die Woord verkondig dat ons in Hom kan glo - dat ons die waarheid van die heil kan ervaar. Die vleesgeworde Woord word egter op so 'n manier deur die sakramente aan ons verkondig dat ons moet verstaan: Die heil is nie net wáár nie - dit is ook werklik. Dit gaan nie net my siel aan nie, maar ook my liggaam. Deur die Gees is die heil by ons aanwesig - nie net in die geestelike, logiese sfeer van gedagtes en begrippe en woorde nie, maar ook in die fisiese, stoflike sfeer. Dit raak ons hele lewe - dit raak ons soos ons is - werklike mense van vlees en bloed.

Sodoende is die sakramente die sterkste moontlike waarborg teen spiritualisme en docetisme in die kerk - op voorwaarde dat dit nie sélf verspiritualiseer word nie.

Dié gevaar bestaan natuurlik altyd in die reformatoriese kerk - waar die reaksie teen Rome so sterk is, en waar die pneumatologiese duiding van die sakramente so sterk beklemtoon word. Daar moet net verstaan word dat die Gees die stoflike elemente van die sakrament gebruik - 
dat Hy op 'n bepaalde - vir ons onbegryplike - manier daarin is. Dan ervaar ons die wonder dat ons - begeesterde stof wat ons is - die heil van Christus in die stof kan ervaar (die elemente van die sakramente) alhoewel op die wyse van die Gees.

\section{DIE GEHEIM BLY}

Bogaande strompelende gang, was 'n poging om in die rigting van 'n antwoord te beweeg. Uiteindelik is 'n mens egter ten diepste daarvan bewus dat die antwoord waarby jy uitkom nie heeltemal bevredig nie net soos alle ander antwoorde wat in die geskiedenis van kerk en teologie gegee is, nie heeltemal bevredig nie; wat 'n mens tot die gevolgtrekking bring dat die geheim van die sakramente eintlik onontrafelbaar is, en dat dit nie werklik ten volle in 'n definisie raakgevat kan word nie. Dit is egter immers ook so, dat wie tevrede gestel kan word met 'n definisie, nog lank nie die sakramente ken nie. Wat belangrik is, is dat die sakrament nie soseer verstaan wil wees nie. Dit wil ervaar en beleef word. Al verstaan jy niks daarvan nie, kan jy tot jou vreugde ondervind hoedat die krag van die sakrament 'n kruk onder die arm van jou struikelende geloof word. Histories was dit so dat die sakramente bedien en die seën van hierdie bediening ervaar is voordat daar 'n poging aangewend is om 'n sakramentsleer te formuleer. So gebeur dit nog vandag. Die individuele gelowige het nie nodig om die sakramente te verstaan voordat hy die seën daarvaan kan ervaar nie. Hy moet hulle net in geloof ontvang en gebruik.

Hierdie oorweging ontneem die kerk egter nie die verantwoordelikheid om tog te probeer sê hoe hy die sakramente verstaan nie. Dit ontneem hom ook nie die verantwoordelikheid om dit in elke nuwe tyd nuut te probeer sê nie. Die belydenisskrifte het dit op 'n onvergelyklike manier gesê, maar hierbo is tog aangetoon dat die woordgebruik (nie die essensie van wat gesê is nie!) van so 'n aard is dat dit misverstande by moderne mense wakker maak. Wat verder hieronder volg is ' $n$ poging om die wesenlike wat deur die kerk in verband met die sakramente gesê is, in 'n paar woorde saam te vat.

Die "oer-sakrament" en die eintlike, diepste misterie, is dit dat die opgestane Christus wesenlik in sy kerk aanwesig is en een liggaam met hom is (Ef 5: 29-32). En dit word geopenbaar deur die medium van die Woord en die sakramente - maar nie so dat Woord en sakrament as losvan-mekaar-staande of selfs teenoor-mekaar-staande groothede gesien kan word nie. Daar is inteendeel 'n wesenlike verbinding van teken en 
Woord. Wat deur die Woordverkondiging as bewussynsinbeelding geskied, word deur die sakramente gesimboliseer. Beide Woord en sakrament dui 'n bepaalde werklikheid aan (die van die teenwoordigheid van Christus) maar dan so dat deur die aanduiding, hierdie werklikheid vir die mense werksaam word. Woord én sakrament maak dus die teenwoordigheid van Christus ' $n$ werklikheid en wel só dat die een die ander nodig het om die volle, radikale werklikheid van Christus se teenwoordigheid by die kerk te openbaar. Die een kan gevolglik nie sonder die ander nie.

Die teenwoordigheid van Jesus Christus in sy kerk is egter nie 'n stoflike-materiële werklikheid nie, maar 'n pneumatologiese. Hy is in die Woord en in die sakramente aanwesig op die wyse van die Gees. Daarom is dit ' $n$ aanwesigheid wat nie deur die sintuie nie, maar deur die geloof, onderskei moet/kan word.

Die teenwoordigheid van Jesus Christus in die gemeente en die gemeenskap met Hom, is eweneens 'n saak wat net deur die geloof onderken kan word. En die geloof is 'n saak van die Gees - deur die Gees in die lewe geroep en in die lewe gehou. In en deur die geloof herken die deelnemer aan die sakrament daarin die teenwoordigheid van Christus wat hy daagliks op 'n ander manier ervaar. Die teenwoordigheid is egter nie (weer eens!) materieel in die elemente van die sakrament te soek nie, maar veel eerder in die gesamentlike kerklike (geloofs-) gemeenskap, wat besig is om die sakrament te vier. Christus is dus as Persoon aanwesig in die gebeure as sodanig - die gelowige gemeenskap, besig om die sakrament te vier.

Die sakrament is dus ' $n$ werktuig van die Gees. Dit is ' $n$ instrument waardeur God die Gees die gemeente wil verseker van die pneumatologiese teenwoordigheid van sy Here tot sy heil. Dit is dus, soos die klassieke terminologie dit uitdruk, ' $n$ middel in die hand van die Gees om die beloftes van God in ons te verseël en om pande te wees van sy goedheid en genade teenoor ons en om ons geloof te voed en te onderhou. Dit het wel deeglik met ons heil te make, deurdat dit ons op 'n unieke manier, waarby ons in ons totaliteit (dws geestelik en liggaamlik) betrek is, konfronteer met die neerbuigende liefde en genade van God in Christus.

Daarom lui die uitspraak van die Reformasie - God is goed vir ons: Sodat ons makliker en beter kan verstaan en glo, gebruik Hy ook die stoflike om ons aan te spreek en ons tot steun te wees op die geloofspad na die heil. 


\section{Literatuurverwysings}

A. Naslaanwerk

- Religion in Geschichte und Gegenwart

- The Interpreters Dictionary of the Bible

B. Ander

BERKHOF H 1973. Christelijk Geloof. GF Callenbach.

CALVYN: Institusie (Vertaal deur A Sizoo). Delft: WD Meinema.

HEYNS JA 1978. Dogmatiek. NG Kerkboekhandel.

OTT HEINRICH 1973. Die Antwort des Glaubens. Kreuz Verlag.

POLMAN ADR. Onze Nederlandsche Geloofsbelijdenis. Franeker: T Wever.

TILLICH PAUL 1968. Systematic Theology. Nisbet.

VAN NIFTRIK GC 1961. Kleine Dogmatiek. Nijkerk: Callenbach. 